\title{
Release of Enzymes from Lysosomes by Irradiation and the Relation of Lipid Peroxide Formation to Enzyme Release
}

\author{
By E. D. WILLS AND A. E. WILKINSON \\ Department of Biochemistry, Medical College of St Bartholomew's Hospital, London, E.C. 1
}

(Received 30 September 1965)

\begin{abstract}
1. Acid phosphatase, cathepsin and $\beta$-glucuronidase are released from rat-liver lysosomes by irradiation in vitro. Enzyme release is detectable after a dose of $1 \mathrm{krad}$ and increases with dose up to $100 \mathrm{krads}$. 2. Maximum radiation effects were observed when the lysosomes were kept for $20 \mathrm{hr}$. at $4^{\circ}$ or $20^{\circ}$ after irradiation. 3. An atmosphere of nitrogen considerably decreases enzyme release from lysosomes. 4. Enzyme release is enhanced by ascorbic acid and decreased by vitamin E. 5. Irradiation causes formation of lipid peroxides in lysosomes, and enzyme release increases with lipid peroxide formation. 6. It is suggested that lipid peroxide formation leads to rupture of the lysosome membrane and allows release of the contained hydrolytic enzymes.
\end{abstract}

It has been suggested (Bacq \& Alexander, 1961) that cell damage which results from exposure to ionizing radiation may be due to a disruption of cellular organization, so that enzymes come into contact with substrates from which they are separated in normal cells. The lysosomes, containing many powerful hydrolytic enzymes such as cathepsins, phosphatases and nucleases (de Duve, Pressman, Gianetto, Wattiaux \& Appelmans, 1955), could be, according to this hypothesis, important targets for irradiation. Liberation of hydrolytic enzymes from the lysosomes would clearly result in extensive damage to proteins, nucleic acids and other molecules in the cell. Studies have been made of lysosomal enzymes liberated after irradiation of animals in vivo. Spleen and liver have been removed after wholebody doses of 100-700 rads, homogenized and centrifuged. The concentrations of nucleases and some other enzymes released into the supernatant after centrifugation have been found to increase after irradiation (Goutier-Pirotte \& Goutier, 1962 ; Roth, Bukovsky \& Eichel, 1962; Roth \& Hilton, 1963; Pierucci \& Regelson, 1965).

Release of enzymes from lysosomes by irradiation may be either a result of a direct effect of irradiation on the lysosomal membrane or of some indirect effect such as the liberation of a hormone. Rahman (1963) suggested that enzyme release from the lysosomes was an indirect effect and was a consequence of thyroid-hormone action. A study of the effect of irradiation on lysosomes isolated from normal animals in vitro is clearly desirable, because in such experiments indirect effects of hormones can be eliminated. Few studies of this type have been made. Okada \& Peachey (1957) found some release of deoxyribonuclease from the mitochondrial-lysosomal fraction, and Desai, Sawant \& Tappel (1964) demonstrated release of acid phosphatase and $\beta$-glucuronidase. Sottocasa, Glass \& De Bernard (1965), however, failed to find any release of $\beta$-glucuronidase or $\beta$-galactosidase from the mitochondrial-lysosomal fraction of heart with doses of 440rads. Most irradiations of lysosomes in vitro have been carried out under a very limited range of experimental conditions and, to assess the importance of a direct effect of radiation on lysosome membranes in vivo, it was considered desirable to study lysosomes irradiated in vitro much more extensively.

Membrane damage may result from the formation of lipid peroxides, as has been demonstrated in erythrocytes (Tsen \& Collier, 1960), and as peroxides are formed in irradiated-tissue lipids (Wills \& Rotblat, 1964) we have attempted to measure lipid peroxides formed in irradiated lysosomes and to correlate enzyme release with increase of lipid peroxide. Most of the experiments described in the present paper were carried out with the mitochondrial-lysosomal fraction of liver as described by de Duve and other workers in this'field (Gianetto \& de Duve, 1955; Dingle, 1961). Hydrolytic enzymes are well established as components of the lysosomes (de Duve et al. 1955) but it is clear that the lipid peroxide measured might be wholly or partly associated with the mitochondria and not with the lysosomes.

Methods so far described for the purification of lysosomes (Beaufay \& Berthet, 1963; Sawant, Shibko, Kumta \& Tappel, 1964) are long and 
tedious and therefore not really suitable for radiation studies. In view of this a method has been devised for the purification of lysosomes which is based on a technique suggested by Rahman \& Lindenbaum (1964) in which a $10-30 \%(w / v)$ sucrose gradient is used. It is described in detail in the Methods section.

\section{METHODS}

Animals. Male or female Wistar rats weighing $200-400 \mathrm{~g}$. were used in all experiments. They were given food and water ad lib.

Buffer solutions. Phosphate buffers were prepared from $\mathrm{NaH}_{2} \mathrm{PO}_{4}$ and $\mathrm{Na}_{2} \mathrm{HPO}_{4}$, and tris-HCl buffers as described by Dawson, Elliott, Elliott \& Jones (1959).

Tissue fractionation. Livers were removed from freshly killed rats and immediately placed in ice-cold $0.25 \mathrm{M}$-sucrose. Tissue (8g.) was then homogenized in a Potter-type homogenizer with two full strokes of the pestle. The resulting homogenate was made up to $80 \mathrm{ml}$. with $0.25 \mathrm{M}$-sucrose and fractionated by the method of Dingle (1961). The mitochondria and lysosomes were sedimented by centrifuging at $10000 \mathrm{~g}$ for $20 \mathrm{~min}$. in an MSE High Speed 18 centrifuge, and the resulting pellet was rinsed once with $0.25 \mathrm{M}$-sucrose. Finally, the sediment was resuspended in $0.25 \mathrm{M}$-sucrose or $0 \cdot 125 \mathrm{M}-\mathrm{KCl}$. Suspensions thus contained mitochondria and lysosomes from $0 \cdot 1 \mathrm{~g}$. of liver $/ \mathrm{ml}$. and this concentration was used in all experiments unless another concentration is specified.

Preparation of purified lysosomes. A modification of the technique suggested by Rahman \& Lindenbaum (1964) was used. Mitochondria containing lysosomes were prepared from a $10 \%(w / v)$ rat-liver homogenate by the method of Dingle (1961). The sediment was suspended in $0.25 \mathrm{M}$ sucrose $(2.5 \mathrm{ml}$. of sucrose soln. $/ \mathrm{g}$. of liver) and a $10 \mathrm{ml}$. sample was layered on to a $10-30 \%(w / v)$ continuous sucrose gradient (total volume $30 \mathrm{ml}$.). The suspension was then centrifuged for $1 \mathrm{hr}$. at $2700 \mathrm{~g}$. The upper $20 \mathrm{ml}$. of the supernatant containing the lysosomal fraction was removed, centrifuged at $30000 \mathrm{~g}$ for $20 \mathrm{~min}$. and the sediment, which contained most of the lysosomes, was resuspended in $0.38 \mathrm{M}$-sucrose $(4.5 \mathrm{ml}$. of sucrose soln./g. of liver). Measurements of cytochrome oxidase and determinations of nitrogen showed that about $90 \%$ of the mitochondria contained in the mitochondrial-lysosomal fraction had been removed by this process.

A 'heavy-mitochondrial' suspension was obtained by resuspending the sediment from the gradient centrifugation in $30 \%(w / v)$ sucrose $(4.5 \mathrm{ml}$. of sucrose $/ \mathrm{g}$. of liver).

Irradiations. The $15 \mathrm{Mev}$ linear accelerator was used for most irradiations. For the electron irradiations, samples of tissue particles (5 or $10 \mathrm{ml}$.) were placed in small sodaglass tubes $(2.5 \mathrm{~cm} . \times 7 \cdot 8 \mathrm{~cm}$.) at $1 \mathrm{~m}$. from the exit port of the accelerator. The radiation from the linear accelerator is delivered in pulses $1.3 \mu$ sec. in duration and the pulse repetition frequency is $400 / \mathrm{sec}$. At the place where the samples were irradiated the normal dose rate was $12 \mathrm{rads} /$ pulse, giving a dose rate during the pulse of $9 \cdot 25$ megarads/ sec. The mean dose rate for exposures of more than one pulse was about $4.8 \mathrm{krads} / \mathrm{sec}$. The total exposure usually varied from 82 pulses, giving a dose of $1 \mathrm{krad}$, to 8200 pulses, giving a total dose of $100 \mathrm{krads}$, but in a few experiments very large doses up to a maximum of $800 \mathrm{krads}$ were given. The dosimetry was checked by means of Perspex (Boag, Dolphin \& Rotblat, 1958) and by using $\mathrm{FeSO}_{4}$. Low doses of X-rays, in the range $250-16000 \mathrm{rads}$, were given in some experiments by using a $250 \mathrm{kv}$ therapy $\mathrm{X}$-ray machine. Samples in tubes similar to those used for electron irradiation were placed against the exit window of the machine. The maximum dose rate was $750 \mathrm{rads} / \mathrm{min}$.

Enzyme assays. The enzymes were assayed in two forms: (a) the free enzyme, and (b) the available enzyme. The free enzymes, which were actually liberated from the lysosomes, were determined in the supernatant produced after centrifuging the lysosomes at $10000 \mathrm{~g}$ for $10 \mathrm{~min}$. The available enzymes were assayed on the whole suspension under iso-osmotic conditions, sucrose being added to the incubation mixture to bring the final concentration of sucrose to that of the original suspending medium. This was $0.25 \mathrm{M}$ for the mitochondrial-lysosomal fraction and $0.38 \mathrm{M}$ for the purified lysosomes.

To determine the maximum quantity of each enzyme present in the lysosomes the mitochondrial-lysosomal fraction or purified lysosomes were treated for $2 \mathrm{~min}$. in an MSE ultrasonic disintegrator. The sediment was centrifuged at $10000 \mathrm{~g}$ for $10 \mathrm{~min}$. and enzyme activities were determined in the supernatant. This procedure was necessary because hypo-osmotic treatment of the lysosomes for $20 \mathrm{hr}$. at $4^{\circ}$ did not always give maximum release of enzymes.

Release of enzyme by irradiation or by other means is expressed in terms of a percentage of the total units released by ultrasonic treatment.

Cathepsin was assayed by a modification of the method described by Anson (1938). The incubation mixture contained $2 \%(\mathrm{w} / \mathrm{v})$ haemoglobin $(3 \mathrm{ml}),. 0 \cdot 2 \mathrm{~N}-\mathrm{HCl}(1 \mathrm{ml}$.$) and$ the lysosome suspension $(2 \mathrm{ml}$.). The mixture was incubated at $37^{\circ}$ and samples ( $1 \mathrm{ml}$.) were removed at $0,5,10$ and $15 \mathrm{~min}$. after addition of the enzyme solution or suspension. Protein was precipitated by the addition of $5 \%(w / v)$ trichloroacetic acid $(2 \mathrm{ml}$.), and the tyrosine and tyrosine peptides released were determined by the addition of Folin-Ciocalteu phenol reagent.

Acid phosphatase was assayed with disodium phenyl phosphate as substrate at $37^{\circ}$ (Gutman \& Gutman, 1938, 1940) or with $p$-nitrophenyl phosphate (Bessey, Lowry \& Brock, 1946). In each method samples were removed at intervals as described for cathepsin determination. $\beta$ Glucuronidase was assayed by the method of Fishman, Springer \& Brunetti (1948).

Velocities of hydrolysis were determined by plotting curves and taking initial slopes.

Cytochrome-oxidase activity of the mitochondria present was measured by the method of Cooperstein \& Lazarow (1951).

Lipid peroxides. The extent of lipid peroxidation was measured by the colorimetric thiobarbituric acid method (Wilbur, Bernheim \& Shapiro, 1949), but in many experiments, to avoid interference by sucrose, which produces a colour, the incubation was performed at $80^{\circ}$ instead of $100^{\circ}$ (Fortney \& Lynn, 1964).

The 'peroxide' measured by this method is strictly not peroxide as such. Malonaldehyde is believed to be split off during the peroxidation of the unsaturated fatty acids and pure malonaldehyde gives an identical colour (Patton \& Kurtz, 1951). The 'thiobarbituric acid value' may 
therefore be expressed in terms of $\mathrm{m} \mu$ moles of malonaldehyde and is used to indicate the degree of lipid peroxidation in tissue particles.

It has been established that $E_{535}$ of the colour produced in the thiobarbituric acid method is greatly increased by the addition of $\mathrm{Fe}^{2+}$ or $\mathrm{Fe}^{3+}$ to the reaction mixture (Wills, 1964). In many experiments extinction values obtained without iron were therefore compared with those when $\mathrm{Fe}^{2+}(1 \mathrm{mM})$ was present.

\section{RESULTS}

\section{Enzyme release from lysosomes after irradiation}

Release of enzymes from control preparations. A proportion of the total lysosomal enzyme content was always released in non-irradiated control preparations. The extent of this release depended on the medium in which the lysosomes were suspended, the temperature and the time after preparation. Thus the mean percentage of total acid-phosphatase release in $0.25 \mathrm{M}$-sucrose after incubation for $1 \mathrm{hr}$. at $4^{\circ}$ was $3 \cdot 1 \%$, after $20 \mathrm{hr}$. at $4^{\circ}$ it was $20.4 \%$ and after $20 \mathrm{hr}$. at $20^{\circ}$ it was $27.2 \%$. Also, $15.7 \%$ of the total $\beta$-glucuronidase was released after $20 \mathrm{hr}$. at $4^{\circ}$. The percentages of enzyme released in individual control experiments are stated in the Tables and Figures.

Effect of variation of dose. The free acid phosphatase released from lysosomes was determined after irradiation of the mitochondrial-lysosomal fraction ( $10 \mathrm{ml}$. in $0.25 \mathrm{M}$-sucrose) by electron doses in the range $1-800 \mathrm{krads}$. The lysosomes were kept at $4^{\circ}$ before, during and after the irradiation. At $1 \mathrm{hr}$. after the irradiation the suspension was centrifuged at $10000 \mathrm{~g}$ for $10 \mathrm{~min}$. and enzyme determinations were made on the supernatant. Under these conditions very small amounts of enzymes were released from the lysosomes. For example, $50 \mathrm{krads}$ caused the release of only $6 \%$ of total acid phosphatase. If, however, the lysosomes were left for $20 \mathrm{hr}$. at $4^{\circ}$ or $20^{\circ}$ after the irradiation and then centrifuged a significant quantity of acid phosphatase was released from the lysosomes into the supernatant.

Free acid phosphatase was measurable after a dose of $1 \mathrm{krad}$ and increased with dose up to $100 \mathrm{krads}$ (Fig. 1). Very high doses, e.g. $800 \mathrm{krads}$, did not release significantly more enzyme than 100 krads. Free acid phosphatase was very radioresistant, and a dose of $800 \mathrm{krads}$ did not inhibit the enzyme that had been extracted from lysosomes by ultrasonic disintegration. The proportions of $\beta$-glucuronidase released by electron doses in the range 5-50krads were similar to those found for acid phosphatase (Table 1).

Release of enzymes during storage of irradiated lysosomes. If the lysosomes were kept at $4^{\circ}$ for $1 \mathrm{hr}$. after irradiation a very small proportion of the

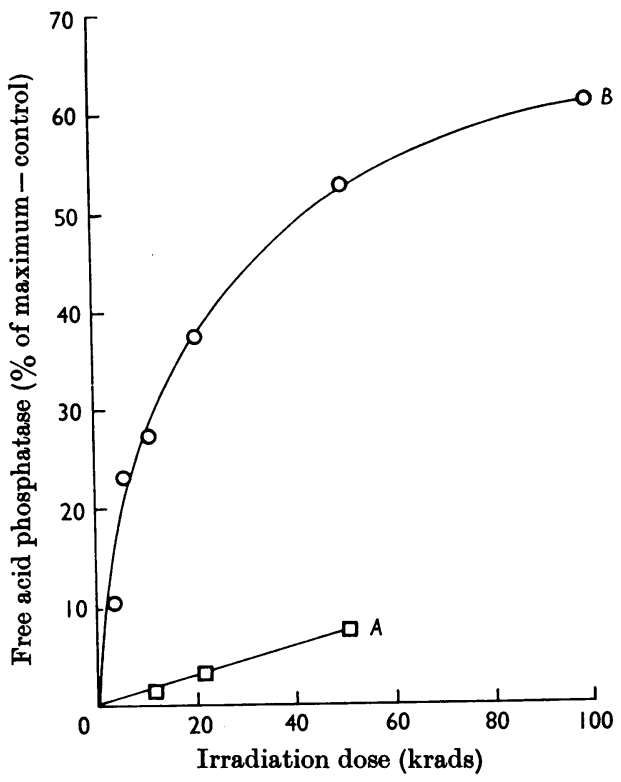

Fig. 1. Release of acid phosphatase from irradiated liver mitochondrial-lysosomal fraction. Curve $A$ ( $\square$ ), acid phosphatase released when suspension was kept at $4^{\circ}$ for $1 \mathrm{hr}$. after the irradiation (control, $3 \cdot 1$ units); curve $B(O)$, acid phosphatase released when suspensions were kept at $20^{\circ}$ for $20 \mathrm{hr}$. after the irradiation (control, 27.2 units). Units of acid phosphatase are expressed as percentages of the maximum enzyme less the enzyme released in nonirradiated controls.

Table 1. Release of acid phosphatase and $\beta$-glucuronidase from irradiated lysosomes

Samples (10 ml.) of the mitochondrial-lysosomal suspension were irradiated in $0.125 \mathrm{M}-\mathrm{KCl}$ in $0.05 \mathrm{M}$-phosphate buffer, $\mathrm{pH} 7 \cdot 0$. After irradiation samples were incubated for $1 \mathrm{hr}$. at $37^{\circ}$. Enzyme activity is expressed as a percentage of the maximum free activity. Actual control values are in parentheses and values for irradiated suspensions are shown as increases over these control values.

$\begin{array}{ccc}\begin{array}{c}\text { Irradiation } \\ \text { dose (krads) }\end{array} & \begin{array}{c}\text { Increase of free } \\ \text { acid phosphatase } \\ (\%)\end{array} & \begin{array}{c}\text { Increase of free } \\ \beta \text {-glucuronidase } \\ (\%)\end{array} \\ 0 \text { (control) } & 0 \cdot 0(40 \cdot 0) & 0 \cdot 0(\mathbf{3 0} \cdot 4) \\ 2 & 3 \cdot 1 & 1 \cdot 5 \\ 5 & 3 \cdot 9 & 5 \cdot 1 \\ 10 & 13.9 & 10 \cdot 2 \\ 20 & 14 \cdot 6 & 14 \cdot 5 \\ 50 & 38 \cdot 5 & 49 \cdot 2\end{array}$

total acid phosphatase was released into the medium. Thus $6 \%$ of the total acid phosphatase was released by $50 \mathrm{krads}$. The proportion of total lysosomal enzyme released increased with time and 
was considerable after $20 \mathrm{hr}$. at $4^{\circ}$, as described in the preceding section. Storage of lysosomes at $-20^{\circ}$ for $20 \mathrm{hr}$. after irradiation with $20 \mathrm{krads}$ prevented radiation-induced release of acid phosphatase. Irradiated lysosomes kept at $20^{\circ}$ for $20 \mathrm{hr}$. also released a large proportion of their total enzyme content and some release occurred if the lysosomes were kept for $2 \mathrm{hr}$. at $20^{\circ}$ or $37^{\circ}$ after irradiation. Incubation at $20^{\circ}$ or $37^{\circ}$, however, often caused the release of a considerable proportion (about 50\%) of the lysosomal enzymes from the non-irradiated controls, so that the enhanced release due to irradiation was decreased in proportion. Thus, for example, after $3 \mathrm{hr}$. incubation at $37^{\circ} 57.4 \%$ of the total lysosomal cathepsin activity was released from control suspensions and $84.4 \%$ from suspensions irradiated with $50 \mathrm{krads}$.

Effect of composition of the medium on enzyme release. In most of the experiments lysosomes were suspended in unbuffered $0.25 \mathrm{M}$-sucrose $(\mathrm{pH} 7 \cdot 0)$ but effects of suspending lysosomes in buffered ionic media were also studied. Mitochondrial-lysosomal fractions were suspended in $0.125 \mathrm{M}$-potassium chloride in $0.02 \mathrm{M}$-phosphate buffer, $\mathrm{pH} 7 \cdot 0$, and irradiated with $20 \mathrm{krads}$ of electrons. After the irradiation the suspension was divided into two parts, one part being kept at $4^{\circ}$ and the other at $20^{\circ}$ for $20 \mathrm{hr}$. Suspensions were then centrifuged at $10000 \mathrm{~g}$ for $20 \mathrm{~min}$. and the quantities of free acid phosphatase and $\beta$-glucuronidase compared with those released from non-irradiated control suspensions and with those from lysosomes suspended in and irradiated in $0.25 \mathrm{M}$-sucrose. Suspensions of non-irradiated lysosomes kept in the potassium chloride medium released a large quantity of enzyme, and although radiation did cause an increase in the free enzyme the net effect of radiation was only about one-third of that normally observed when lysosomes were irradiated in sucrose. When the $\mathrm{pH}$ of the potassium chloride suspension of lysosomes was varied over the range $\mathrm{pH} 6 \cdot 0-8 \cdot 0$ enzyme release was not significantly different from

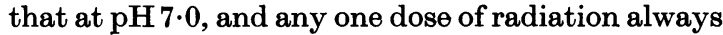
released much less extra enzyme from lysosomes suspended in potassium chloride than from lysosomes suspended in sucrose.

To examine the effect of ions on enzyme release, mitochondrial-lysosomal fractions were suspended in $0.25 \mathrm{M}$-sucrose, $0.25 \mathrm{M}$-sucrose in $0.04 \mathrm{M}$-potassium chloride and $0.25 \mathrm{M}$-sucrose in $0.02 \mathrm{M}$-tris-hydrochloric acid buffer, pH 7.4. Duplicate samples of each suspension were irradiated with $20 \mathrm{krads}$ and in addition samples of each suspension were kept as controls. At $1 \mathrm{hr}$. after irradiation a $5 \mathrm{ml}$. sample of the particles in each medium was centrifuged and acid phosphatase was determined in the supernatant. Samples of irradiated and control particles in each medium were incubated at $20^{\circ}$ for $20 \mathrm{hr}$. and then centrifuged, and the quantity of acid phosphatase liberated into the supernatant was determined. A $20 \mathrm{krad}$ dose of irradiation caused the release of a large quantity of acid phosphatase from particles suspended in sucrose but much less if tris buffer was present (Table 2). Similar results were obtained if potassium chloride $(0.04 \mathrm{M})$ was added to the sucrose. This decreased radiation effect was primarily a result of instability of lysosomes in the presence of ions, the addition of which, either as potassium chloride or buffer salts, to the sucrose medium led to a considerable, and often erratic, decrease in the stability of the lysosome membrane.

Relation between available enzyme and free enzyme. The activity of the available enzyme was always greater than that of the free enzyme, but radiation caused only a small enhancement of enzyme

\section{Table 2. Effect of buffer salts on release of acid phosphatase from irradiated liver mitochondrial-lysosomal fractions}

Samples ( $5 \mathrm{ml}$.) of the mitochondrial-lysosomal fraction of rat liver $(0 \cdot 6 \mathrm{mg}$. of $\mathrm{N} / \mathrm{ml}$.) were irradiated in $0.25 \mathrm{M}$-sucrose or $0.25 \mathrm{M}$-sucrose in $0.02 \mathrm{M}$-tris-HCl buffer, $\mathrm{pH} 7 \cdot 4$. After irradiation the samples were incubated at $4^{\circ}$ or $20^{\circ}$ for $20 \mathrm{hr}$. Enzyme activity is expressed as a percentage of the maximum free activity. Actual control values are in parentheses and values for irradiated suspensions are shown as increases over these control values.

\begin{tabular}{cclc}
$\begin{array}{c}\text { Irradiation } \\
\text { dose (krads) }\end{array}$ & $\begin{array}{c}\text { Incubation } \\
\text { temp. }\end{array}$ & \multicolumn{1}{c}{$\begin{array}{c}\text { Suspension } \\
\text { medium }\end{array}$} & $\begin{array}{c}\text { Increase of free } \\
\text { acid phosphatase } \\
(\%)\end{array}$ \\
0 (control) & $4^{\circ}$ & Sucrose & $0 \cdot 0(18 \cdot 4)$ \\
20 & 4 & Sucrose & $8 \cdot 3$ \\
0 & 4 & Sucrose-tris buffer & $30 \cdot 0$ \\
20 & 4 & Sucrose-tris buffer & $38 \cdot 2$ \\
0 (control) & 20 & Sucrose & $0 \cdot 0(55 \cdot 5)$ \\
20 & 20 & Sucrose & $25 \cdot 5$ \\
0 & 20 & Sucrose-tris buffer & $22 \cdot 3$ \\
20 & 20 & Sucrose-tris buffer & 20.9
\end{tabular}




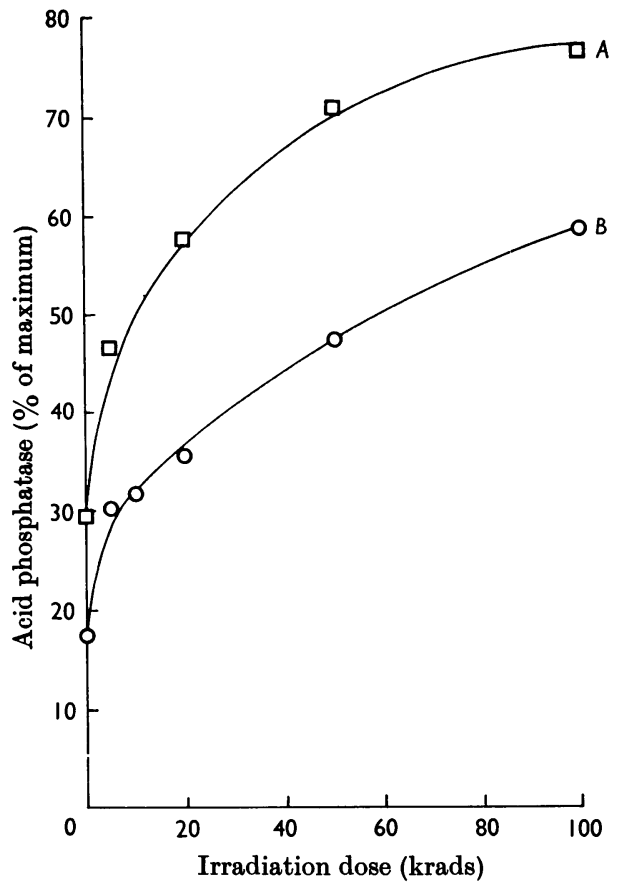

Fig. 2. Comparison of the effect of radiation on the 'available' acid phosphatase and 'free' acid phosphatase of liver lysosomes. Curve $A(\square)$, available acid phosphatase; curve $B(O)$, free acid phosphatase.

activity $30 \mathrm{~min}$. after irradiation, the increase of available enzyme being slightly greater than the increase of free enzyme. When mitochondriallysosomal suspensions were irradiated and then kept for $20 \mathrm{hr}$. at $4^{\circ}$, the radiation significantly increased the acid-phosphatase activity both of the whole suspension and of the supernatant. Irradiation causes a larger increase in substrate-available enzyme than of free enzyme (Fig. 2).

\section{Lipid 'peroxide' formation in irradiated mitochondrial-lysosomal fractions}

'Peroxide' formation. Many membranes are known to contain polyunsaturated fatty acids as part of the structure (Van Deenen, De Gier, Houtsmuller, Montfoort \& Mulder, 1963) and it is likely that the lysosomal membrane is similar in this respect. Pure unsaturated fatty acids, or lipids separated from animal tissues, readily form peroxides when irradiated in aqueous emulsions (Wills \& Rotblat, 1964), and it is therefore conceivable that the formation of peroxides of unsaturated fatty acids in the phospholipids of lysosome membranes may result in membrane

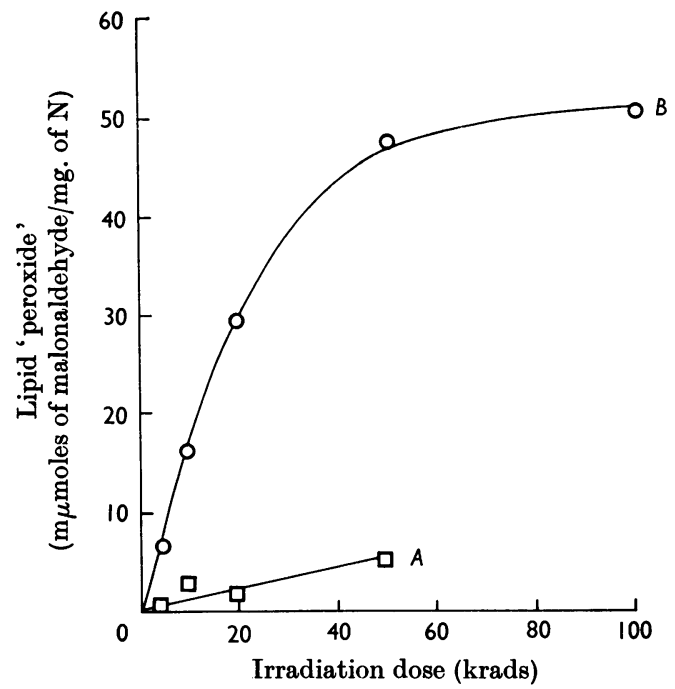

Fig. 3. Lipid 'peroxide' formation in irradiated liver mitochondrial-lysosomal fraction. Curve $A(\square)$, immediately after the irradiation (control, 6.6 units); curve $B(O)$, $20 \mathrm{hr}$. at $20^{\circ}$ after the irradiation (control, 10.2 units). Lipid 'peroxide' values are expressed as increases over the non-irradiated controls.

damage. This damage may then culminate in enzyme release.

Suspensions $(10 \mathrm{ml}$.) in $0.25 \mathrm{M}$-sucrose or $0.125 \mathrm{M}$ potassium chloride were irradiated with $2,5,10$ and $20 \mathrm{krads}$ and an additional $10 \mathrm{ml}$. was kept as control. Lipid 'peroxide' concentration was determined 2 min. after the irradiation by the thiobarbituric acid test on $1 \mathrm{ml}$. samples. A sample (2ml.) of each irradiated and control suspension was incubated at $37^{\circ}$ and samples of each suspension were kept at $4^{\circ}$ and $20^{\circ}$ for $20 \mathrm{hr}$. after the irradiation. Immediately after the irradiation there was little increase of 'peroxide' but after a short incubation at $37^{\circ}$ or after a longer incubation at $4^{\circ}$ or $20^{\circ}$ large increases of 'peroxide' were found (Fig. 3). Addition of inorganic iron during the determination markedly increases 'peroxide' values (Wills, 1964). The increase in thiobarbituric acid values after irradiation was much greater when $\mathrm{Fe}^{2+}$ was added during the determination (Table 3).

Effect of ascorbic acid. Ascorbic acid is a powerful catalyst for lipid 'peroxide' formation in normal tissues (Wolfson, Wilbur \& Bernheim, 1956). Incubation of mitochondrial-lysosomal fractions in the presence of ascorbic acid caused a large increase of 'peroxide', which was accompanied by release of acid phosphatase (Table 4). Radiation (10 krads) followed by incubation for $1 \mathrm{hr}$. at $37^{\circ}$ caused a further significant increase in 'peroxide' concentration but this was accompanied by a very small, and 
Table 3. Effect of $\mathrm{Fe}^{2+}$ on thiobarbituric acid values in the irradiated mitochondrial-lysosomal fraction of liver

Samples (5 ml.) of the mitochondrial-lysosomal fraction of liver in $0 \cdot 25 \mathrm{M}$-sucrose $(0 \cdot 2 \mathrm{~g}$. of liver $/ \mathrm{ml}$.) were irradiated with $0,0.5,1,2,5,10$ and $20 \mathrm{krads}$. Thiobarbituric acid determinations (with and without $\mathrm{Fe}^{2+}$ ) were made on $1 \mathrm{ml}$. samples of each suspension kept at $4^{\circ}$ for $50 \mathrm{~min}$. after the irradiation and then again $20 \mathrm{hr}$. after the irradiation.

$\begin{array}{ccccc}\begin{array}{c}\text { Irradiation } \\ \text { dose (krads) }\end{array} & \overbrace{\text { Control }}^{E_{535} 50 \mathrm{~min} . \text { after irradiation }} & +\mathrm{Fe}^{2+}(1 \mathrm{mM}) & \overbrace{\text { Control }} & +\mathrm{Fe}^{2+}(\mathbf{1 ~ m M}) \\ 0 & 0.205 & 0.485 & 0.524 & 0.780 \\ 0.5 & 0.200 & 0.469 & 0.559 & 0.803 \\ 1 & 0.201 & 0.490 & 0.599 & 0.829 \\ 2 & 0.200 & 0.420 & 0.655 & 0.905 \\ 5 & 0.221 & 0.490 & 0.730 & 0.955 \\ 10 & 0.222 & 0.500 & 0.830 & 1.368 \\ 20 & 0.238 & 0.515 & 0.895 & 1.818\end{array}$

Table 4. Effect of ascorbic acid on lipid peroxidation and release of acid phosphatase from the mitochondrial-lysosomal fraction after irradiation

Samples (10 ml.) of a mitochondrial-lysosomal suspension $(0.6 \mathrm{mg}$. of $\mathrm{N} / \mathrm{ml}$.) were irradiated in $0 \cdot 125 \mathrm{M}-\mathrm{KCl}$ in 0.01 M-phosphate buffer, pH 7.0. Ascorbic acid was added before irradiation. After irradiation samples were incubated at $37^{\circ}$ for $1 \mathrm{hr}$. Enzyme activity is expressed as a percentage of the maximum free activity. Actual control values for enzyme activity and thiobarbituric acid reaction (TBA value; m $\mu$ moles of malonaldehyde/ mg. of N) are in parentheses and the values for irradiated suspensions are shown as increases over these control values.

Irradiation
dose (krads)
0 (control)
10
0
10

$\quad$ Addition to
suspension medium
None
None
Ascorbic acid $(0.5 \mathrm{~mm})$
Ascorbic acid $(0.5 \mathrm{M})$

Increase of TBA
value
$\begin{gathered}0 \cdot 0(12 \cdot 6) \\ 2 \cdot 0 \\ 91 \cdot 8 \\ 110 \cdot 4\end{gathered}$

Increase of free acid phosphatase

$5 \cdot 1$

$11 \cdot 7$

$12 \cdot 9$

Table 5. Effect of vitamin $E$ on lipid peroxidation and release of acid phosphatase from the mitochondrial-lysosomal fraction after irradiation

Samples $(10 \mathrm{ml}$.) of rat-liver mitochondrial-lysosomal suspension $(0.6 \mathrm{mg}$. of $\mathrm{N} / \mathrm{ml}$.) were irradiated in $0.25 \mathrm{M}$ sucrose. Vitamin $\mathbf{E}$ (Roche Ephynal solution diluted with 0.25 M-sucrose) was added before irradiation. After irradiation samples were incubated for $20 \mathrm{hr}$. at $4^{\circ}$. Enzyme activity is expressed as a percentage of the maximum free activity. Actual control values for enzyme activity and thiobarbituric acid reaction (TBA value; $\mathbf{m} \mu \mathrm{moles}$ of malonaldehyde/mg. of $\mathrm{N}$ ) are in parentheses and the values for irradiated suspensions are shown as increases over these control values.

Irradiation
dose (krads)
0 (control)
10
0
10

\begin{tabular}{lc}
\multicolumn{1}{c}{ Addition to } & Increase of TBA \\
suspension medium & value \\
None & $0.0(7 \cdot 2)$ \\
None & $5 \cdot 0$ \\
Vitamin E $(1.4 \mu \mathrm{g} . / \mathrm{ml})$. & -1.6 \\
Vitamin E $(1.4 \mu \mathrm{g} . / \mathrm{ml})$. & -1.8
\end{tabular}

Increase of free acid phosphatase

$26 \cdot 3$

$20 \cdot 0$ probably insignificant, additional release of acid phosphatase (Table 4).

Addition of EDTA ( $1 \mathrm{~mm}$ ) completely abolished the catalytic effect of ascorbic acid $(0.5 \mathrm{~mm})$ and also the increase in 'peroxide' produced by irradia- tion. This effect of EDTA supports the view that a metal-catalysed oxidation is involved in this 'peroxide' formation. A possible mechanism has been discussed by Wills (1965).

Effect of vitamin $E$. Vitamin $\mathbf{E}$ is well known as 

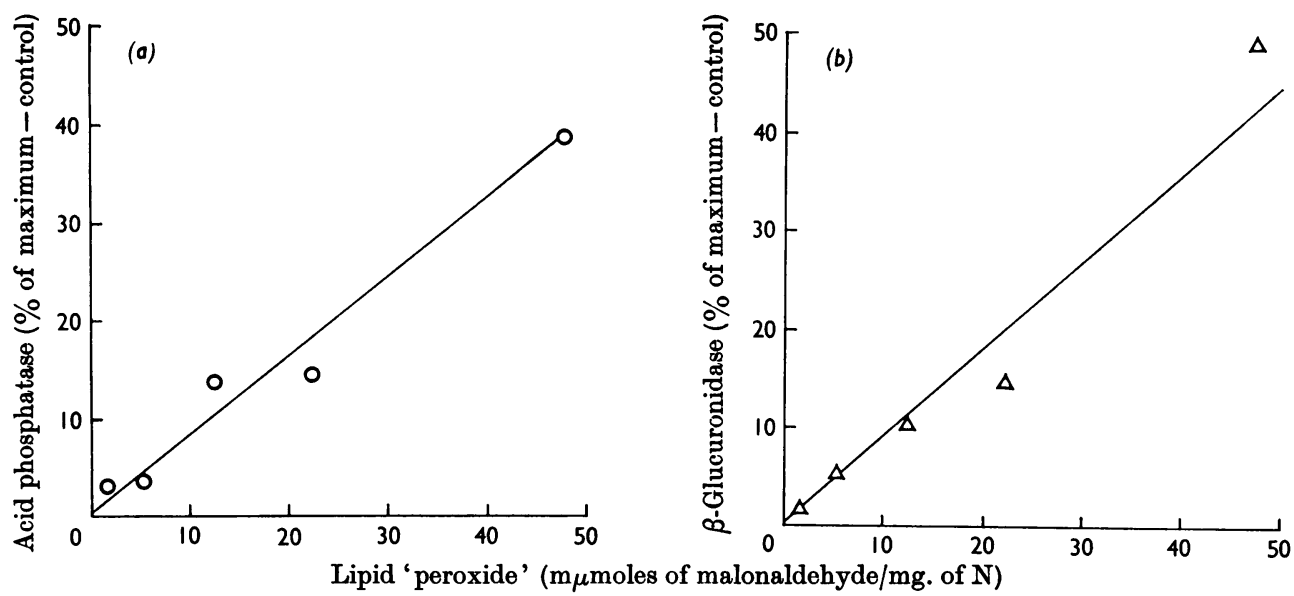

Fig. 4. Relation between increase of lipid 'peroxide' and the release of acid phosphatase (a) and $\beta$-glucuronidase (b) from liver lysosomes irradiated with doses in the range 0-50krads. Enzyme units are expressed as in Fig. 1. Lipid 'peroxide' values are expressed as increases over non-irradiated controls.

an antioxidant and as an effective protective agent against the formation of lipid peroxides (Tappel, 1962). Vitamin $\mathbf{E}$ decreased the 'peroxide' concentration in control mitochondrial-lysosomal suspensions and abolished the increase in 'peroxide' caused by irradiation. Vitamin $E$ also caused a release of enzyme in control experiments but protected the lysosomes against further radiationinduced release of enzyme (Table 5).

\section{Relation between enzyme release and 'peroxide' formation in lysosomes}

As discussed in the preceding section, it is possible that enzyme release from lysosomes might be a result of peroxide formation in the membrane. This hypothesis was investigated by measuring the increase of 'peroxide' formation in lysosomes caused by irradiation and comparing this with the release of acid phosphatase and $\beta$-glucuronidase. Mitochondrial-lysosomal suspensions $(10 \mathrm{ml}$.) in $0.125 \mathrm{M}$-potassium chloride in 0.05 M-phosphate buffer, pH 7.0, were irradiated with $0,2,5,10,20$ and $50 \mathrm{krads}$. The suspensions were incubated for $1 \mathrm{hr}$. at $37^{\circ}$ after the irradiation, $1 \mathrm{ml}$. of each was removed for determination of 'peroxide' concentration and the remainder was centrifuged at $10000 \mathrm{~g}$ for $20 \mathrm{~min}$. Good correlation was observed between enzyme release and 'peroxide' concentration (Fig. 4).

\section{Experiments with purified lysosomes}

Effects of irradiation and 'peroxide' formation in purified lysosomes. Suspensions of purified lysosomes ( $5 \mathrm{ml}$.) prepared from $22 \mathrm{~g}$. of liver suspended in $0.38 \mathrm{M}$-sucrose were irradiated with $0,5,10,20$ and $50 \mathrm{krads}$. They were centrifuged as soon as possible after irradiation. No detectable quantity of enzyme was released by any radiation dose used. In a second series of experiments with the same doses of radiation the suspensions were incubated for $20 \mathrm{hr}$. at $4^{\circ}$ before determinations of 'peroxide' and acid phosphatase were carried out on the whole suspension. 'Peroxide' increased markedly after irradiation and was accompanied by a release of acid phosphatase (Table 6).

If the heavy-mitochondrial fraction, which remained as a sediment after the density-gradient centrifugation, was irradiated, little or no release of enzyme could be detected and, further, although irradiation caused 'peroxide' formation this was much less than in the lysosome fraction (Table 6).

Irradiation of purified lysosomes in nitrogen and in oxygen. Samples of purified lysosomes in $0.38 \mathrm{M}$ sucrose were introduced into Thunberg tubes, and the air was replaced by nitrogen. Similar samples in Thunberg tubes were left in equilibrium with air. Anaerobic and aerobic suspensions were irradiated with $0,5,10,20$ and $50 \mathrm{krads}$ and then left at $4^{\circ}$ for $20 \mathrm{hr}$. Incubation in nitrogen caused a marked decrease in 'peroxide', which was accompanied by a similar decrease in release of acid phosphatase (Table 7).

\section{DISCUSSION}

The availability of the lysosomal enzymes, cathepsin, $\beta$-glucuronidase and acid phosphatase, to their substrates is substantially increased by irradiation in vitro. Further, irradiation in vitro 
Table 6. Lipid peroxidation and available acid phosphatase after irradiation of heavy mitochondria and purified lysosomes

Samples $(6 \mathrm{ml}$.) of heavy mitochondria $(0.8 \mathrm{mg}$. of $\mathrm{N} / \mathrm{ml}$.) and purified lysosomes $(0.3 \mathrm{mg}$. of $\mathrm{N} / \mathrm{ml}$.) were irradiated in $0.88 \mathrm{M}$ - and $0.38 \mathrm{M}$-sucrose respectively. After irradiation the samples were incubated for $20 \mathrm{hr}$. at $4^{\circ}$. In the lysosomal fraction the maximum enzyme activity is $162 \mathrm{~m} \mu$ moles of product formed/min. and in the heavy-mitochondrial fraction the maximum enzyme activity is $64 \mathrm{~m} \mu \mathrm{moles}$ of product formed/min. Enzyme activity is expressed as a percentage of the total activity. Actual control values for enzyme activity and thiobarbituric acid reaction (TBA value; $m \mu$ moles of malonaldehyde $/ \mathrm{mg}$. of $\mathrm{N}$ ) are in parentheses and the values for irradiated suspensions are shown as increases over these control values.

\begin{tabular}{|c|c|c|c|}
\hline Fraction & $\begin{array}{c}\text { Irradiation } \\
\text { dose (krads) }\end{array}$ & $\begin{array}{c}\text { Increase of TBA } \\
\text { value }\end{array}$ & $\begin{array}{c}\text { available acid } \\
\text { phosphatase (\%) }\end{array}$ \\
\hline Lysosomal fraction & $\begin{array}{l}0 \text { (control) } \\
5 \\
10 \\
20 \\
50\end{array}$ & $\begin{array}{r}0.0(163 \cdot 5) \\
89 \cdot 0 \\
97 \cdot 7 \\
99 \cdot 5 \\
105 \cdot 5\end{array}$ & $\begin{array}{c}0 \cdot 0(28 \cdot 7) \\
29 \cdot 3 \\
49 \cdot 5 \\
51 \cdot 5 \\
63 \cdot 3\end{array}$ \\
\hline Heavy-mitochondrial fraction & $\begin{array}{l}0 \text { (control) } \\
5 \\
10 \\
20 \\
50\end{array}$ & $\begin{array}{l}0 \cdot 0(13 \cdot 7) \\
2 \cdot 8 \\
5 \cdot 3 \\
10 \cdot 8 \\
21 \cdot 3\end{array}$ & $\begin{array}{l}0.0(53 \cdot 2) \\
1 \cdot 6 \\
1 \cdot 6 \\
1 \cdot 6 \\
0.0\end{array}$ \\
\hline
\end{tabular}

\section{Table 7. Lipid peroxidation and available acid phosphatase after irradiation of purified lysosomes under aerobic and anaerobic conditions}

Samples $(2.5 \mathrm{ml}$.) of the suspension, prepared as described in the text, were evacuated and then gassed with $\mathrm{N}_{2}$. These, with control suspensions equilibrated with air, were irradiated and incubated for $20 \mathrm{hr}$. at $4^{\circ}$. Enzyme activity is expressed as a percentage of total enzyme activity. Actual control values for enzyme activity and thiobarbituric acid reaction (TBA value; $\mathrm{m} \mu$ moles of malonaldehyde/mg. of $\mathrm{N}$ ) are in parentheses and values for irradiated suspensions are shown as increases over these control values.

$\begin{array}{cccc}\text { Incubation conditions } & \begin{array}{c}\text { Irradiation } \\ \text { dose (krads) }\end{array} & \begin{array}{c}\text { Increase of TBA } \\ \text { value }\end{array} & \begin{array}{c}\text { Increase of } \\ \text { available acid } \\ \text { phosphatase (\%) }\end{array} \\ \text { Aerobic } & 0 & 0 \cdot 0(40 \cdot 0) & 0 \cdot 0(32 \cdot 3) \\ & 2 & 53 \cdot 1 & 2 \cdot 4 \\ & 5 & 88 \cdot 5 & 2 \cdot 4 \\ \text { Anaerobic } & 10 & 95 \cdot 6 & 6 \cdot 5 \\ & 20 & 144 \cdot 1 & 27 \cdot 2 \\ & 50 & 179 \cdot 1 & 51 \cdot 2 \\ & 0 & 0 \cdot 0(40 \cdot 0) & 0 \cdot 0(28 \cdot 7) \\ & 2 & 14 \cdot 2 & 0 \cdot 0 \\ & 5 & 14 \cdot 2 & 0 \cdot 0 \\ & 10 & 18 \cdot 4 & 0 \cdot 0 \\ & 20 & 18 \cdot 4 & 0 \cdot 0 \\ & 50 & 64 \cdot 4 & 11 \cdot 7\end{array}$

causes liberation of enzymes into the suspending media and this is most likely to be a result of disintegration of the lysosomal membranes. The release of these hydrolytic enzymes normally runs parallel and there is no reason to believe that irradiation causes a preferential release of any one of the lysosomal enzymes studied. Doses that cause appreciable enzyme leakage, namely 5$20 \mathrm{krads}$, are greater than those that cause leakage in vivo (700rads). Neverthless, it is clear that radiation can damage the lysosomal membrane directly and that, with doses of this order, it is not necessary to implicate the intermediary role of hormones or any other factor.

Radiation damage to lysosomes is strictly timedependent and very little enzyme release occurs immediately after the irradiation. Thus it appears that radiation causes some change in the membrane 
that subsequently leads to its rupture. The most marked effects were observed when the lysosomes were stored in sucrose at $4^{\circ}$ for $20 \mathrm{hr}$. after irradiation. Attempts to accelerate the development of radiation damage by incubating at $37^{\circ}$ or $20^{\circ}$ were generally not successful, because, although the irradiated lysosomes liberated a large proportion of their total enzyme content at these temperatures, the non-irradiated lysosomes also liberated enzymes so that the net radiation effect was small. It is possible that in vivo lysosomes are much more stable at $37^{\circ}$ and the radiation effect may be proportionally greater.

Most experiments described in this paper lead to the conclusion that lipid peroxidation is related to, if not the prime cause of, radiation damage to lysosomes. It may be surmised that membrane structure and integrity depend on the unsaturated fatty acids of the phospholipids that form part of the membrane, and that if the double bonds of these acids are oxidized to give 'peroxides' disintegration of the fatty acid chains ensues. This results in membrane leakage or complete rupture. As an example of this process, it has been demonstrated (Tsen \& Collier, 1960) that the erythrocyte membrane becomes much less stable in vitamin $\mathbf{E}$ deficient animals, when 'peroxides' are more readily formed in the membranes.

The thiobarbituric acid method for lipid 'peroxide' determination is not above criticism (Philpot, 1963). Nevertheless, it is very convenient and has been extensively used for lipid 'peroxide' determination in tissues (Tappel \& Zalkin, 1959; Bieri \& Anderson, 1960). It is believed that malonaldehyde is the source of the colour reaction (Patton \& Kurtz, 1951). A study of peroxidation and peroxide formation in pure linolenic acid has demonstrated that the increase in thiobarbituric acid value parallels the increase of peroxide concentration as determined by ultraviolet absorption, by oxidation of ferrous thiocyanate or iodometrically (Wills, 1964; Wills \& Rotblat, 1964). It should be emphasized that, since this method determines a peroxide breakdown product, it does not measure the amount of peroxide present but indicates the total extent of peroxidation. It is this value, and not the amount of lipid peroxide present at any time, that would be expected to correlate with damage caused by peroxidation.

However, the possibility of interference by chromogen production from materials other than lipids must be considered. Interference by sucrose was greatly diminished by using the modification proposed by Fortney \& Lynn (1964). The sucrose blank did not alter after irradiation of $0.25 \mathrm{M}$ sucrose, a $0.5 \mathrm{ml}$. sample giving $E_{535} \quad 0.05$. DNA and deoxyribose sugars are known to produce malonaldehyde on periodate oxidation but serious interference from these sources is unlikely in the fractions investigated. No absorption peaks at 545$550 \mathrm{~m} \mu$ due to formylpyruvic acid could be detected in extracts of mitochondria, the spectrum being identical with that obtained with oxidized linolenic acid emulsion. The possibility that a chromogenic aldehyde may be split off from proteins by irradiation is extremely unlikely at the doses used, and aldehydes other than malonaldehyde, e.g. crotonaldehyde, formaldehyde and acetaldehyde, do not give the characteristic pink colour (Philpot, 1963).

The increased colour intensity of the thiobarbituric acid reaction that is observed when $\mathrm{Fe}^{2+}$ is added during the determination (Wills, 1964) has not been completely explained. It is noteworthy that both irradiation and addition of $\mathrm{Fe}^{2+}$ increases the colour intensity but that the radiation effect is much more marked when $\mathrm{Fe}^{2+}$ is present (Table 3). At $20 \mathrm{hr}$. after the irradiation, a low dose of radiation ( $2 \mathrm{krads})$ caused an extinction increase of 0.131 over the non-irradiated control when no $\mathrm{Fe}^{2+}$ was added, and almost the same increase (0.125) when $\mathrm{Fe}^{2+}$ was present. However, a larger dose of irradiation (20krads) produced an extinction increase of 0.371 over the control with no $\mathrm{Fe}^{2+}$ added and 1.038 when $\mathrm{Fe}^{2+}$ was added (Table 3). It therefore appears that radiation causes an increase in peroxidation of the mitochondriallysosomal fraction but that the availability of non-haem iron in the fraction may be a factor that limits the thiobarbituric acid value when large quantities of lipid 'peroxide' are formed.

After irradiation of mitochondrial-lysosomal fractions the release of hydrolytic enzymes from the lysosomes is closely paralleled by the extent of peroxidation of the particles (Fig. 4). Further, incubation with ascorbic acid, which catalyses 'peroxide' formation, also causes enzyme release (Table 4). Ascorbic acid-catalysed oxidation causes a very large increase of 'peroxide' that does not result in a proportionately large release of enzymes (Table 4). It therefore appears that, although a proportion of 'peroxide' formation may be associated with enzyme release, a large quantity of 'peroxide' may be formed in this fraction that is unrelated to enzyme release. It is highly probable that a considerable proportion of 'peroxide' formed by ascorbic acid is formed in the mitochondria themselves because they contain the large quantities of non-haem iron that appear to be essential for ascorbic acid catalysis of 'peroxide' formation (Wills, 1965). Vitamin E possesses surface-active properties and lysosomes were not stable in its presence (Table 5), but it is noteworthy that vitamin $\mathbf{E}$ protected lysosomes against radiationinduced 'peroxide' formation and enzyme liberation (Table 5).

In most experiments mitochondria were present 
with the lysosomes and lipid 'peroxide' measured could have been associated with the mitochondria rather than with the lysosomes. After purification of the lysosomes the major proportion of 'peroxide' formation caused by irradiation is associated with the lysosomes and not with the mitochondria, which form much less 'peroxide' (Table 6). There is therefore little doubt that extensive 'peroxide' formation occurs in the lysosomes after irradiation. When purified lysosomes were irradiated in nitrogen and kept in nitrogen after irradiation both 'peroxide' formation and enzyme release were considerably decreased below the levels observed when lysosomes were incubated in oxygen (Table 7). These experiments emphasize that a post-irradiation oxidative process must be important in enzyme release.

The mechanism of 'peroxide' formation is not clear. It may be a result of direct oxidation of unsaturated fatty acids of the lysosome membrane by free radicals formed in the aqueous phase, as suggested by Wills \& Rotblat (1964). Initial formation of a small quantity of peroxide may then initiate a chain process of autoxidation. Alternatively, metal-catalysed or haemoprotein catalysis may be responsible, as suggested by Wills (1965). According to this hypothesis irradiation would cause disorganization of the lysosome, thus allowing a catalytic metal or haemoprotein to come into close proximity with an unsaturated fatty acid, and subsequently cause the formation of lipid peroxide.

The authors thank Professor J. Rotblat and his colleagues in the Physics and Radiotherapy Departments of St Bartholomew's Hospital for their assistance with irradiations, Professor E. M. Crook for helpful comments and the British Empire Cancer Campaign for grants which made the work possible.

\section{REFERENCES}

Anson, M. L. (1938). J. gen. Physiol. 22, 79.

Bacq, Z. M. \& Alexander, P. (1961). Fundamentals of Radiobiology, 2nd ed., p. 272. London: Pergamon Press Ltd.

Beaufay, H. \& Berthet, J. (1963). Symp. biochem. Soc. 23, 66.

Bessey, O. A., Lowry, O. H. \& Brock, M. J. (1946). J. biol. Chem. 164, 321.

Bieri, J. G. \& Anderson, A. A. (1960). Arch. Biochem. Biophys. 80, 105.
Boag, J. W., Dolphin, G. W. \& Rotblat, J. (1958). Radiat. Res. 8, 589.

Cooperstein, S. J. \& Lazarow, A. (1951). J. biol. Chem. $189,665$.

Dawson, R. M. C., Elliott, D. C., Elliott, W. H. \& Jones, K. M. (1959). Data for Biochemical Research, p. 195. Oxford: The Clarendon Press.

De Duve, C., Pressman, B. C., Gianetto, R., Wattiaux, R. \& Appelmans, F. (1955). Biochem. J. 60, 604.

Desai, I. D., Sawant, P. L. \& Tappel, A. L. (1964). Biochim. biophys. Acta, 86, 277.

Dingle, J. T. (1961). Biochem. J. 79, 509.

Fishman, W. H., Springer, B. \& Brunetti, R. (1948). J. biol. Chem. 173, 449.

Fortney, S. R. \& Lynn, W. S. (1964). Arch. Biochem. Biophys. 104, 241.

Gianetto, R. \& De Duve, C. (1955). Biochem. J. 59, 433.

Goutier-Pirotte, M. \& Goutier, R. (1962). Radiat. Res. $16,728$.

Gutman, A. B. \& Gutman, E. B. (1938). J. clin. Invest. $17,473$.

Gutman, E. B. \& Gutman, A. B. (1940). J. biol. Chem. 136, 201.

Okada, S. \& Peachey, L. D. (1957). J. biophys. biochem. Cytol. 3, 239.

Patton, S. \& Kurtz, G. W. (1951). J. Dairy Sci. 34, 669.

Philpot, J. St L. (1963). Implications of Organic Peroxides in Radiobiology: Radiat. Res. Suppl. no. 3, p. 55.

Pierucci, O. \& Regelson, W. (1965). Radiat. Res. 24, 619.

Rahman, Y. E. (1963). Radiat. Res. 20, 741.

Rahman, Y. E. \& Lindenbaum, A. (1964). Radiat. Res. 21, 575 .

Roth, J. S., Bukovsky, J. \& Eichel, H. J. (1962). Radiat. Res. 16, 27.

Roth, J. S. \& Hilton, S. (1963). Radiat. Res. 19, 42.

Sawant, P. L., Shibko, S., Kumta, U. S. \& Tappel, A. L. (1964). Biochim. biophys. Acta, 85, 82.

Sottocasa, G. L., Glass, G. \& De Bernard, B. (1965). Radiat. Res. 24, 32.

Tappel, A. L. (1962). Vitam. \& Horm. 20, 493.

Tappel, A. L. \& Zalkin, H. (1959). Arch. Biochem. Biophys. $80,326$.

Tsen, C. C. \& Collier, H. B. (1960). Canad. J. Biochem. Physiol. 38, 957.

Van Deenen, L. L. M., De Gier, J., Houtsmuller, U. M. T., Montfoort, A. \& Mulder, E. (1963). In Biochemical Problems of Lipids, vol. 1, p. 404. Ed. by Frazer, A. C. Amsterdam: Elsevier Publishing Co.

Wilbur, K. M., Bernheim, F. \& Shapiro, O. W. (1949). Arch. Biochem. Biophys. 24, 305.

Wills, E. D. (1964). Biochim. biophys. Acta, 84, 475.

Wills, E. D. (1965). Biochim. biophys. Acta, 88, 238.

Wills, E. D. \& Rotblat, J. (1964). Int. J. Radiat. Biol. $8,551$.

Wolfson, N., Wilbur, K. M. \& Bernheim, F. (1956). Exp. Cell Res. 10, 556. 